\title{
8. Finding Bunaq: The homeland and expansion of the Bunaq in central Timor
}

\author{
Antoinette Schapper
}

\section{Introduction}

The Bunaq people occupy a large area of central Timor, straddling both sides of the modern border. Whilst the Bunaq of Lamaknen in West Timor have been the focus of detailed ethnographic research by Louis Berthe and Claudine Friedberg, there is no broader work on the Bunaq in other parts of East and West Timor. This chapter aims to contribute to a better understanding of the region of central Timor by exploring the history of the Bunaq-speaking area as a whole.

The Bunaq are linguistically and socially isolated in central Timor. Bunaq is a Papuan or non-Austronesian language, spoken by approximately 80000 people. They are surrounded on all sides by Austronesian languages: Kemak to the north, Mambai to the east and Tetun to the south and west. The other Papuan languages of Timor - Fataluku, Makasai and Makalero - are located in a contiguous coastal area on the island's eastern tip. ${ }^{1}$ The Bunaq language is widely recognised by the Bunaq and their Austronesian neighbours as 'different', and, while Bunaq is rarely learnt by non-Bunaq, almost all Bunaq are fluent in at least one Austronesian language.

In addition, the Bunaq are typically regarded by their neighbours with disdain, frequently being characterised as a coarse and aggressive people. This view has ensured that the Bunaq have remained somewhat apart from them. What is more, this external perception of their nature has fed into the Bunaq's own traditions, such as the concluding moral of the folk story of two brothers, Asa Paran and Mau Paran: En Emaq g-epal legul. En Bunaq g-epal gol ('The Kemak people have

\footnotetext{
1 More distant relatives are found on the islands of Alor and Pantar to the north of Timor. Together, the Papuan languages of Timor-Alor-Pantar (TAP) form a language family that broke up and dispersed some time before the Austronesian arrival in the region some 3000 years ago. The wider genetic relations of the TAP language family to other Papuan languages of the New Guinea mainland, such as the TransNew Guinea family, remain highly speculative.
} 
long ears. The Bunaq people have small ears.') The metaphor of short versus long ears refers to the contrasting temperaments of the Bunaq (short-tempered and impatient) and the Kemak (quiet and uncomplaining).

These factors of linguistic non-conformity and social isolation have set them apart to some degree. But they have also led to an inclusive cultural attitude on the part of the Bunaq, involving widespread borrowing and adaptation from Austronesian language and society, such that Berthe (1963) was compelled to describe the Bunaq as having a mixed Austronesian-Papuan descent.

This chapter documents the processes of Bunaq expansion, using evidence from oral histories, placenames and data from the dialects of the Bunaq language. A subsidiary aim of this chapter is to illustrate how linguistic materials can be used to supplement and improve the picture of the past presented in oral histories. The data discussed here were collected during field trips in 2006, 2007 and 2009 surveying the Bunaq area.

After a brief outline of the basic principles of dialectology and how they apply to Bunaq in section two, I explore the history of the individual Bunaq areas in section three, showing where and how the Bunaq have expanded into new areas, mingled and partly taken over from groups of Austronesian speakers. Finally, in section four, I discuss the position of the Bunaq in central Timor in light of the traditional Papuan-Austronesian dichotomy. I suggest that, whilst the Bunaq have taken over Austronesian lands, they did not arrive after the Austronesians, but have incorporated many Austronesian features through sustained contact - a form of cultural 'metatypy' (Ross 2006).

\section{Bunaq Geography and Dialectology}

Today the Bunaq-speaking area (Map 8.1) extends in the north from Maliana down to portions of the southern coast of Timor-Leste; it stretches east from the eastern edges of southern Belu regency in West Timor into the western edge of Manufahi subdistrict in Timor-Leste.

Across the wide geographical area in which Bunaq is spoken, there are several different dialects. Dialects are geographical variants of a single language and dialectology is the study of this variation. Dialects are distinguished from one another by the distinct phonological (sounds) and lexical (words) features they display. Features varying between dialects are treated as instances of diachronic divergence from a common ancestor. That is, dialect differences arise when a population of speakers of a single variation-free language in one area replaces an original feature, $\mathrm{X}$, with innovative feature $\mathrm{Y}$, while speakers in another area innovate feature $\mathrm{Z}$ for feature $\mathrm{X}$, while those in still another area retain feature $\mathrm{X}$ as $\mathrm{X}$, and so on. 


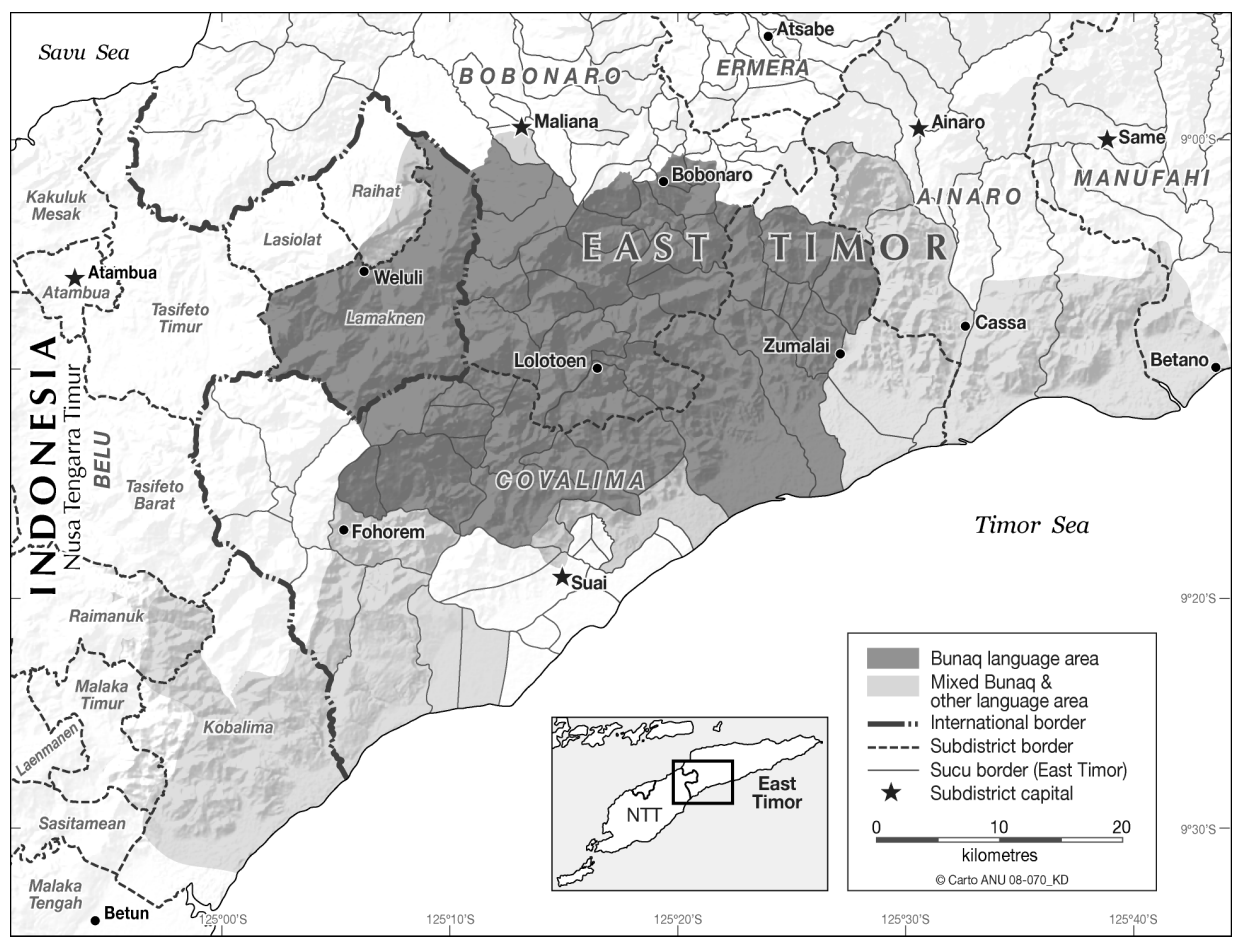

\section{Map 8.1 The extent of the Bunaq language area}

Phonological differences between dialects arise out of sound change across the lexicon - that is, in all words with the sound in question. The most common types of sound change involve replacing one sound with another or the complete loss of a sound. Sound changes are often environmentally conditioned. That is, a change in question may occur only in a defined environment, such as the middle of a word or before another sound of a particular kind, while the same sound remains unaffected in other environments. For example, the medial / $t /$ in words such as 'water' has come to be pronounced as /d/ in some dialects of English, but never an initial / $\mathrm{t} /$ as in the word 'tap'.

Lexical differences between dialects arise in several different ways. A new word may be borrowed from another language with which the speakers in one area are in contact or are influenced by. A lexical item might be innovated - that is, a group of speakers may develop an entirely new word for an object or concept. A lexical innovation may also involve a semantic shift, whereby one word changes its meaning, thus replacing the original word with that meaning.

So, while lexical differences are the result of a new lexical item taking the place of an original lexical item with that meaning, phonological differences involve sounds changing in lexical items that are related to each other. A word can be assumed to be part of the proto-language - the single undifferentiated form of 
the language from which the individual dialects descend-when it is attested across the dialects and shows regularity of sound change. Words that do not show the expected sound changes characteristic of the dialects can typically be explained as borrowings or lexical innovations that have been taken after a sound change has applied in the dialect. The important point here is that sound changes are limited in the space to which and time in which they are active, and so can tell us about the relative chronology of dialect break-ups and thus people movements.

Based on phonological and lexical divisions, the Bunaq language area can be broken up into five major dialects: the South-West dialect, the Lamaknen dialect, the North-East dialect, the Ainaro dialect and the Manufahi dialect. The area covered by each of the dialects is represented in Map 8.3. These dialect regions represent only the major divisions between geographical varieties of Bunaq. It should be borne in mind that each of these dialect regions encompasses a great deal of variation, often with differences being found from one village to the next.

A few examples illustrating the dialect divisions on phonological grounds are provided in Table 8.1. We see that the South-West and Manufahi dialects preserve original ${ }^{*} \mathrm{~d}$ and ${ }^{*} \mathrm{t}$ in all environments. Lamaknen is most radical in having * $\mathrm{d}$ changing to $\mathrm{r}$ both initially and medially, unlike the North-East where $r$ is only an (optional) realisation of $d$ medially. The North-East affricates *t before the vowels i and $\mathrm{u}$; Lamaknen and Ainaro show some limited change of *t to $t$ (a sound represented in English orthography with $\{\mathrm{ch}\}$ as in 'church') before i word-initially, with Lamaknen further merging $f$ with s. Loss of * $w$ and development of final * $r$ into tf together characterise the three eastern dialects, with the subsequent loss of $t f$ in Ainaro and Manufahi. Sporadic loss of initial ${ }^{*} \mathrm{~h}$ is found in the North-East and Ainaro dialects.

A sample of the many lexical features illustrating the dialect divisions is provided in Table 8.2. The maximal differentiation pattern is illustrated by 'big' with each of the dialect areas having a distinct lexeme. The South-West is distinct from all other dialects in having two inalienable nouns, -ip 'wife' and -enen 'husband'; the remaining areas simply use pana 'woman' and mone 'man' for these concepts. For 'sleep', the North-East and Ainaro dialects have innovative malat, while the South-West, Lamaknen and Manufahi reflect proto-Bunaq *tier (cognate with, for example, Oirata taja and Makasai ta?e 'sleep'). In contrast, for 'stand', the South-West and Lamaknen have innovative du?at, while modern net 'stand' in the other dialects has widespread cognates in related Papuan languages (for example, Oirata and Abui nate 'stand'). Ainaro and Manufahi share the borrowing boi 'not want' from Mambai, while only the Ainaro dialect has borrowed au 'I' from Mambai. Both the Ainaro and Manufahi dialects have 
innovated items for 'not exist', the former from hazi? 'disappear', the latter from muel 'be thin'. Finally, Manufahi is distinct from all other dialects in its item for 'exist'.

Table 8.1 Phonological Characteristics of Bunaq Dialects

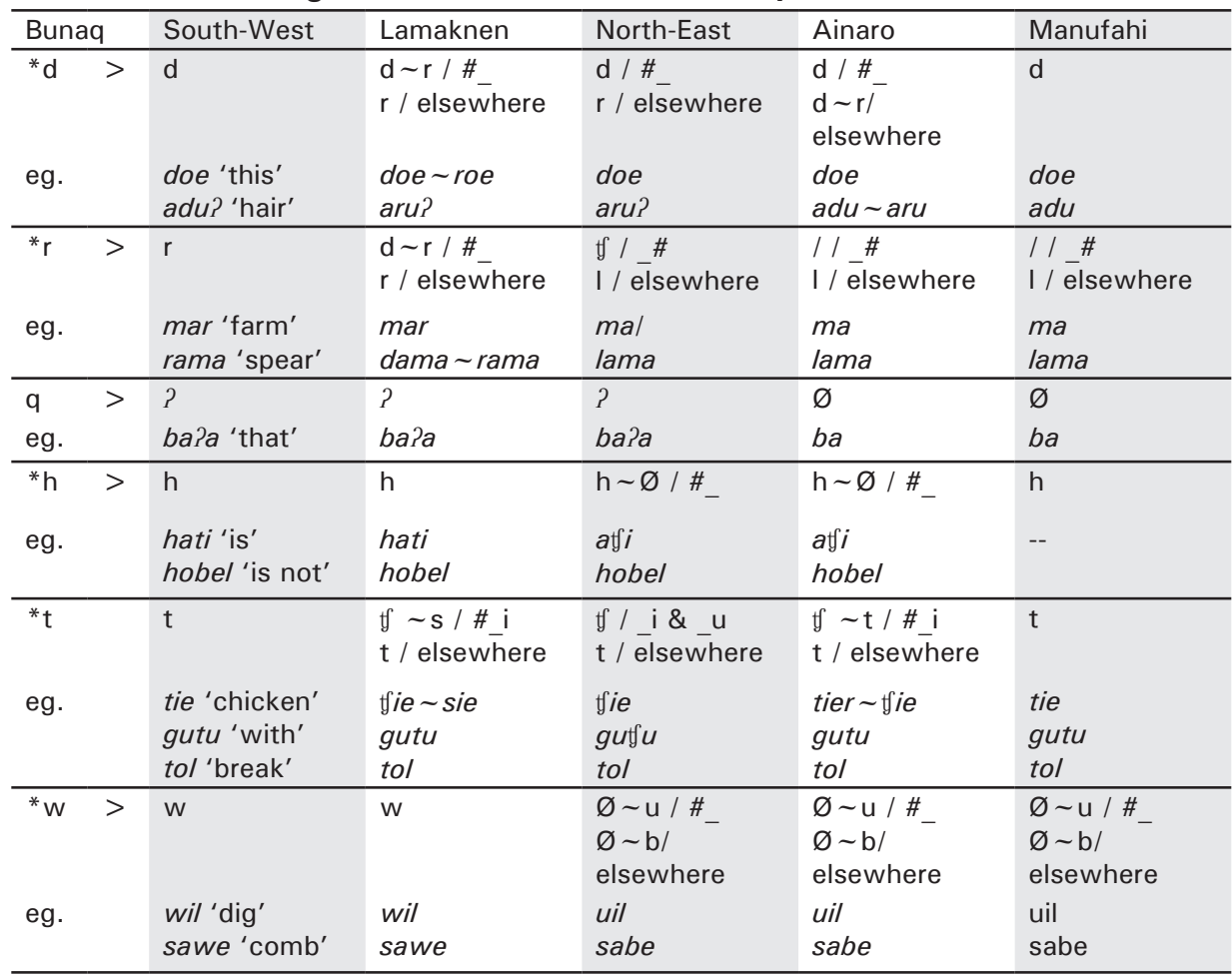

Table 8.2 Lexical Characteristics of Bunaq Dialects

\begin{tabular}{llllll}
\hline & South-West & Lamaknen & North-East & Ainaro & Manufahi \\
\hline 'BIG' & bo?al & masak & tina & gemel & kaman \\
'WIFE' & $-i p$ & pana & pana & pana & pana \\
'HUSBAND' & - enen & mone & mone & mone & mone \\
'SLEEP' & tier & fier & malat & malat & tier \\
'STAND' & du?at & du?at & net & net & net \\
'PLAY' & buku? & buku? & kisa? & buku & neun \\
'NOT WANT' & tia? & fia? & pia? & boi & boi \\
'I' & neto & neto & neto & au & neto \\
'NOT EXIST' & hobel & hobel & hobel & hazi & muel \\
'EXIST' & hati & hati & atfi & hati & hono \\
\hline
\end{tabular}

In the following section, we will see how such dialect data can be applied along with other forms of information to understanding and interpreting the history of the Bunaq in central Timor. 


\section{The Bunaq Dispersal}

We see from Map 8.1 that, far from only having interaction with other peoples on the fringes of their area, the Bunaq also occupy vast tracts of land in which other Austronesian peoples are also settled. As suggested above, the modern dispersal of Bunaq speakers reflects a long history of migration and expansion into new territory. Excessive pressure on land caused by growing populations and the depletion of soil due to the nature of shifting agriculture have forced the Bunaq to look for new farming land over a period of centuries.

Political factors and governmental ventures have also affected modern Bunaq settlement patterns. Ongoing political turmoil and upheaval from the early Portuguese era until today have caused significant population displacements and in particular brought about successive waves of refugees from East Timor into West Timor. Isolated communities have been both drawn by convenience and compelled by successive administrations seeking greater access to the populace into the region of newly constructed roads or as part of agricultural development projects. In what follows, I will look at the evidence of the Bunaq dispersal region by region.

\section{The Bunaq Homeland: Central-eastern Bobonaro and north-eastern Covalima}

In the central-eastern area of Bobonaro and north-eastern Covalima subdistricts (defined by black line on Map 8.4), we find placenames with exclusively Bunaq etymologies, such as Odelgomo (< odel 'monkey', gomo 'owner'), Mapelai (< mape 'eagle', lai 'set') and Zoilpo? (< zoil 'k.o. tree', po?' 'holy'/'sacred').

Outside this core area, we find Bunaq villages with Bunaq placenames alongside Bunaq villages with Austronesian placenames (area defined by grey line on Map 8.3). Bunaq placenames increasingly give way to non-Bunaq ones until all Bunaq villages have non-Bunaq names (grey shaded area). This dispersal of placenames strongly points to the 'homeland' of the Bunaq as being in central-eastern Bobonaro and north-eastern Covalima - the geographical centre of the modern Bunaq-speaking area. If the Bunaq were immigrants to the core area, we would expect to find traces of the previous populations left behind in placenames, as we do outside the core.

Further linguistic evidence for this region being the Bunaq homeland comes from the presence of lexical items in Bunaq dialects that have their origin in the Austronesian languages Kemak and to a lesser extent Mambai. Table 8.3 presents a sample of the items in Bunaq and their source in Kemak and/or Mambai. We can see that these items are borrowed from Austronesian into 
Bunaq, since they can be reconstructed to higher levels of the Austronesian family. That is, they are historically known to be Austronesian words and to have cognates in other Austronesian languages. This directionality of borrowing seems anthropologically more likely since among the items in question are words encoding concepts associated with Austronesian culture-for instance, kin terms such as elder brother/sister, which show the kind of concern for precedence and rank typical of Austronesian society (McWilliam 2007). More recent influence of the Kemak in the north-east of the Bunaq area can be seen in the adoption of an exogenous name. In this region, the Bunaq refer to themselves and their language as Gaiq or Gaeq - a term not used elsewhere and very likely from Mgai, the Kemak name for the Bunaq.

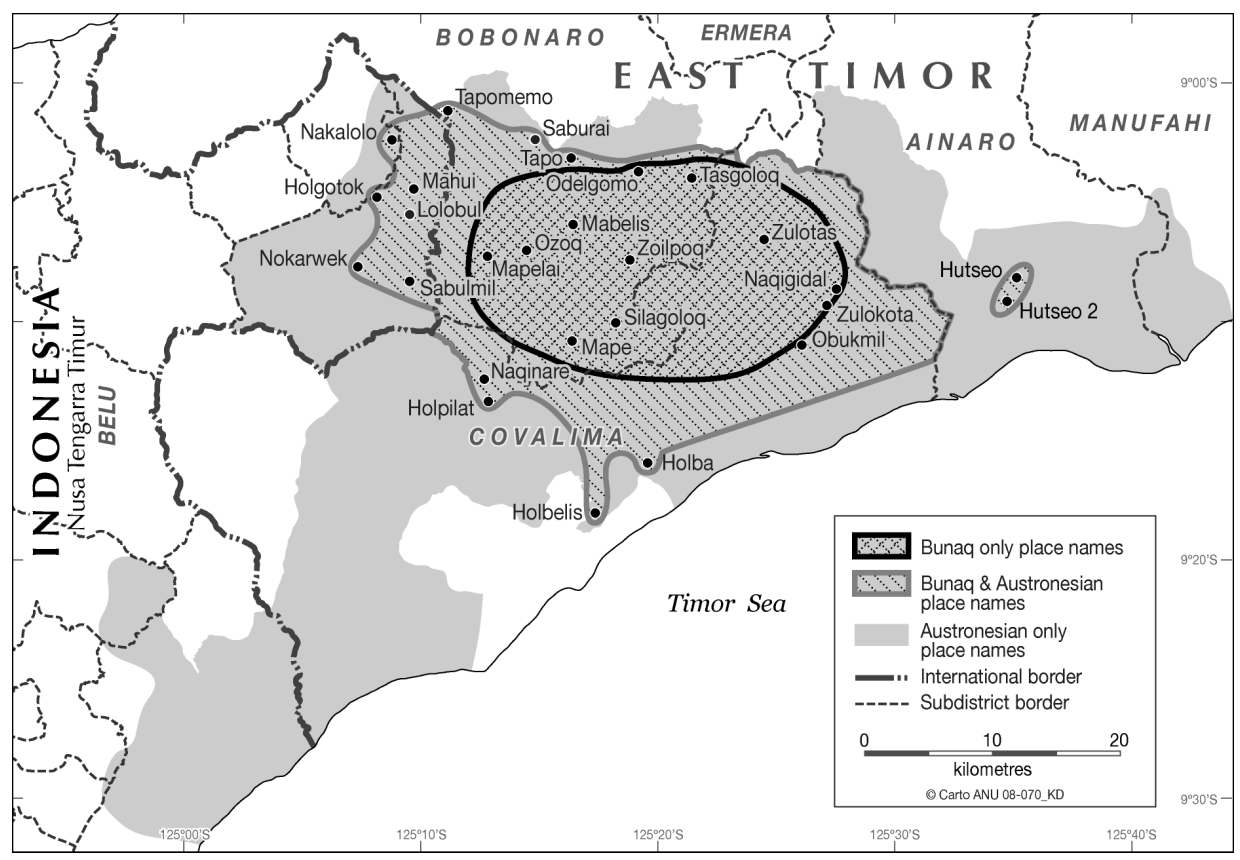

\section{Map 8.2 The relative dispersal of Bunaq and Austronesian placenames}

That these items are found across all Bunaq dialects points to their being present in the proto-language - in other words, present in the Bunaq language before dialect differentiation took place. This means that proto-Bunaq would have had to be spoken in an area that had intense contact with speakers of Kemak and Mambai, or at least where people were speaking the forerunners of these modern languages. The central-eastern area of Bobonaro and northeastern Covalima subdistricts fit precisely this profile, with Kemak and Mambai both close by. Furthermore, the Bunaq of the north-east recognise themselves as historically having been part of the large Likosaen kingdom, which was centred on the Kemak-Tokodede region directly west of Dili (see Spillet 1999:242 ff.). 
The significant influence of this kingdom could explain the apparent ready adoption of Austronesian terms and the concomitant cultural categories by early Bunaq speakers.

Table 8.3 Pan-Bunaq Borrowings from Kemak/Mambai

\begin{tabular}{llll}
\hline Bunaq & & Source & \\
\hline ka?a & 'older brother' & $<$ Kmk ka?a-r & 'older brother' \\
nana & 'older sister' & $<$ Kmk nana-r & 'older sister (of male)' \\
tata & 'ancestor' & $<$ Kmk tata-r & 'grandparent, ancestor' \\
lihur & 'thousand' & $<$ Kmk rihur & 'thousand' \\
taho? & 'low cloud' & $<$ Kmk taho? & 'cloud, mist' \\
huan & 'heart' & $<$ Kmk huan & 'heart' \\
hul & 'moon' & $<$ Mam. hul & 'moon' \\
si & 'meat' & $<$ Mam. si $\sim$ sis, Kmk si & 'meat' \\
le & 'light' & $<$ Mam. le $\sim$ lel & 'sun' \\
to & 'year' & $<$ Mam. to $\sim$ ton, Kmk to & 'year' \\
loi & 'good' & $<$ Kmk/Mam. mloi & 'good' \\
hui & 'wild' & $<$ Kmk/Mam. hui & 'wild'
\end{tabular}

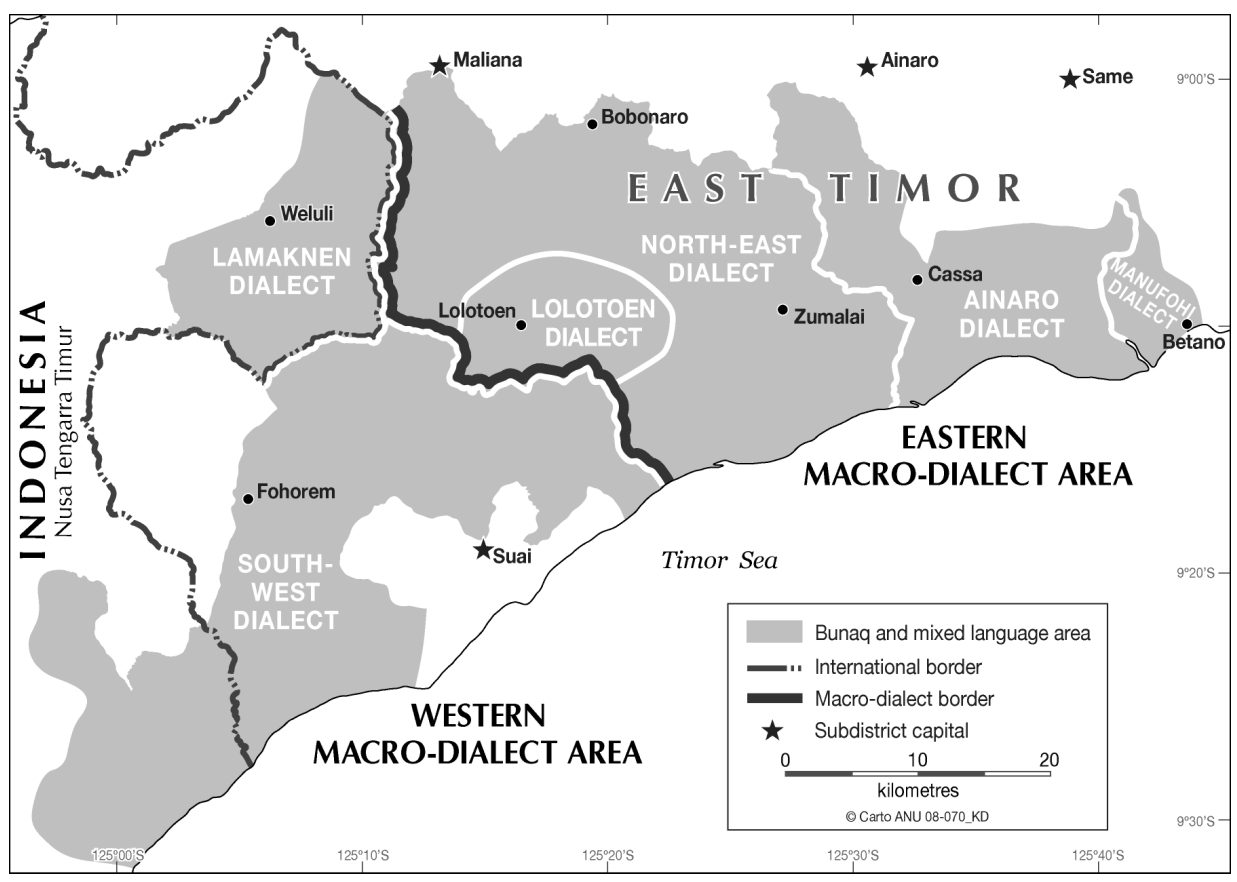

Map 8.3 The major Bunaq dialects 


\section{The North-West Bunaq Area}

The north-west Bunaq area encompasses the lands south of Maliana in TimorLeste and in the Lamaknen subdistrict and a small neighbouring area of Raihat subdistrict in the Belu regency of Indonesian West Timor (Map 8.4).

According to their own oral histories, the Bunaq in Lamaknen came to the area from the east. When they arrived they found either Tetun or Dawan people, depending on the particular account, with whom they freely mixed. This view of the past is supported by the many village names in Lamaknen and Raihat that have at least partial Austronesian etymologies - for example: Duarato > Tet. dua dato 'two kings', Aitoun $>$ Tet./Daw. ai 'tree' toun '?'. The area is also home to many placenames with Bunaq etymologies - for example: in West Timor, Nakalolo > naka 'mud' and lolo 'mountain', and in Timor-Leste, Sabulai > sabul 'citrus' and lai 'put'. The significant admixture of Austronesian placenames and the absence of Austronesian speakers in this area point to the Bunaq having been established in this region before the beginning of the historical period.

The dialectal evidence suggests that Lamaknen has been the crossroads for movements of Bunaq people from the North-East and South-West dialect regions. The Lamaknen dialect is intermediate between these two. The linguistic feature best illustrating this split is the postposition 'at'. In the South-West, the postposition is realised as $n i$, while in the North-East it is no. In Lamaknen, speakers use no and ni interchangeably. Lexically, Lamaknen shares most in common with the South-West, retaining items in common with them, such as buku' 'play', duat 'stand' and tier 'sleep', but patterns with the North-East in using terms such as taho 'cloud' and in using mone 'man' and pana 'woman' only for 'husband' and 'wife', respectively. Phonologically, Lamaknen shows the influence of the North-East with the development of $t$ from *t and $r$ from *d, but has taken its own direction with these sound changes. That is, in Lamaknen *t became $t$ ' and then s only before the vowel i, whereas in the North-East the change was only to $f$, but applied in more environments, before the vowels i and u. Similarly, in Lamaknen *d became $r$ not only word-medially but also initially, whereas in the North-East the change was limited to the medial position. The point here is that, whilst obviously being influenced by linguistic developments through contact with the North-East, their presence in Lamaknen Bunaq is limited, with conservative features of the South-West dominating.

The divided linguistic features of Bunaq Lamaknen are historically grounded in the fact that much of the region was subject to territorial disputes between the north-eastern kingdom of Lamakhitu and the kingdom of Lakmaras situated in the south of modern-day Lamkanen and strongly allied to Bunaq peoples in the south-west. For instance, Pélissier (1996:174 ff.) describes a series of battles in 1897 for lands in Lamaknen with Lamakhitu, while the changing ownership of the Maukatar enclave (described in the following section) was rooted in the dispute between Lamakhitu and Lakmaras. 


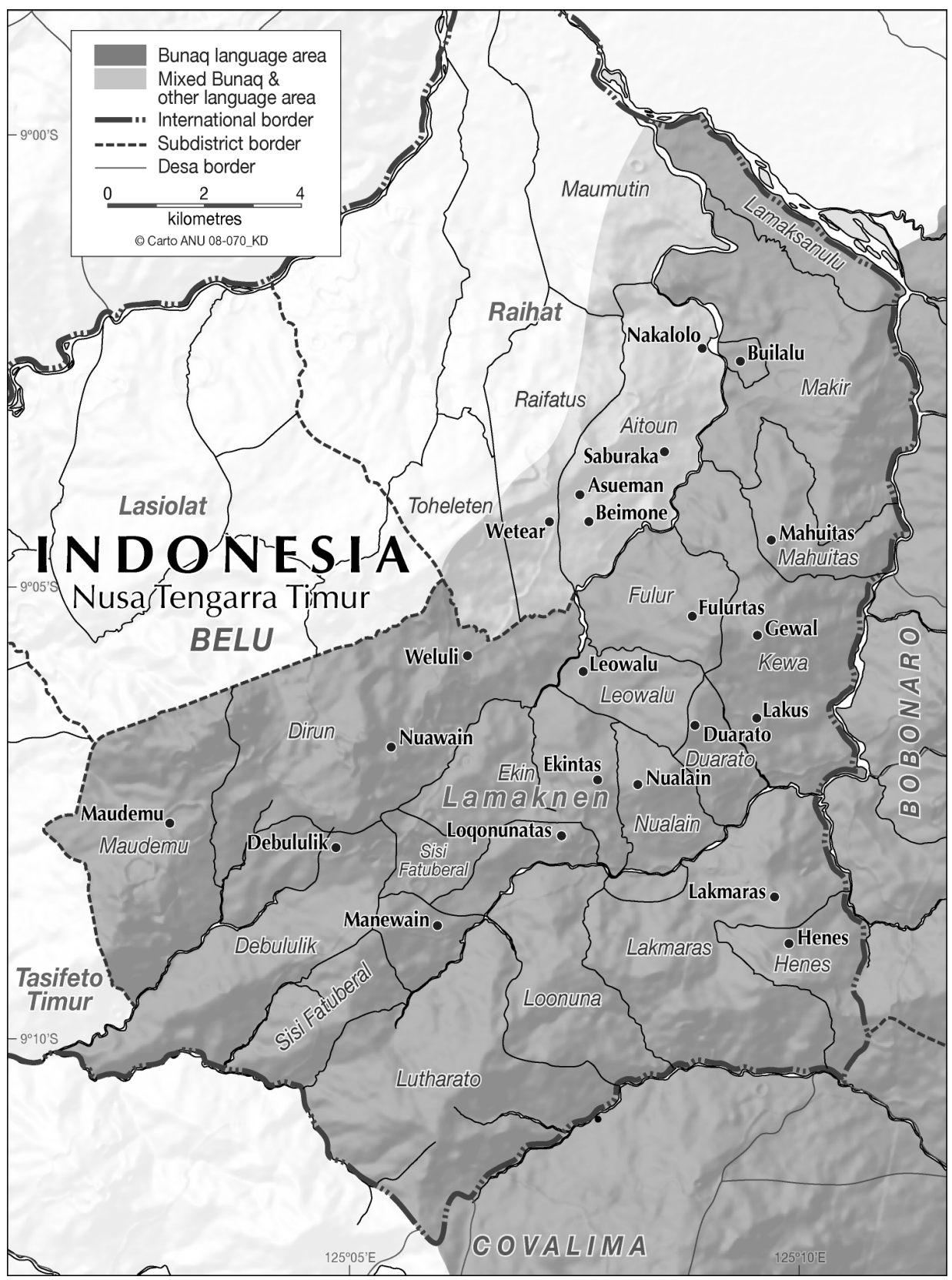

Map 8.4 Bunaq villages in Lamaknen and Raihat 
More recently, the Bunaq from the east have been establishing new lowland villages around Maliana. Although these villages were founded several generations ago, individual lowland villages still trace themselves back to a particular upland village and maintain ritual ties with it. For example, the upland village of Tapo? ( $<t a$ ? ' $a x e^{\prime}$ po? 'holy') is the origin for a lowland village situated on the alluvial plains south-east of Maliana. The name of the village of origin is even reflected in that of the new village: Tapomemo? (literally: 'sweet Tapo?).

Conflicts of the past half-century have also brought additional waves of Bunaq from East Timor into West Timorese Lamaknen and Raihat. At the end of World War II, Bunaq people fearing reprisals due to their support for the Japanese arrived in Lamaknen from the East Timorese village of Lebos and established the village of Lakus after a grant of land from the then loro (king), A. Beretalo. Today Lakus people maintain distinct elements of a north-eastern dialect but often lexically coloured by Lamaknen dialect. For instance, Lakus has the North-East feature in which ' replaces $r$ finally, but applies them to otherwise typical south-western/Lamaknen dialect items such as fie? for 'sleep' where the local Lamaknen dialect has tfier.

More refugees arrived in 1975 when the Indonesian Army moved into East Timor. Fighting destroyed whole villages in Lamaknen; Friedberg reports that her field site, the village of Henes, had ceased to exist when she returned to Lamaknen after 1975 (personal communication). In 1999, following the vote for independence in East Timor, many more refugees arrived in Lamaknen and Raihat and set rambling bush huts on roadsides, many of which remain to this day.

Table 8.4 Examples of Tetun Ritual Vocabulary in Bunaq Lamaknen

\begin{tabular}{|c|c|c|c|}
\hline \multicolumn{2}{|c|}{ Bunaq Lamaknen } & \multicolumn{2}{|l|}{ Tetun } \\
\hline molo lok & 'offer betel' & lok & 'offer in hospitality' \\
\hline pa?ol sau & $\begin{array}{l}\text { 'corn harvest festival', } \\
\text { 'lift ban on eating corn' }\end{array}$ & sau & 'lift a prohibition/ban' \\
\hline muk ukon & 'govern', lit. 'land rule' & rai uku & 'govern', lit. 'land rule' \\
\hline ukur & 'power, authority' & ukur & $\begin{array}{l}\text { 'ritual, ceremony', lit. 'cords } \\
\text { linking edges of loom' }\end{array}$ \\
\hline uma metan & 'ruling house' & uma metan & $\begin{array}{l}\text { lit. 'black house', used in ritual } \\
\text { contexts in reference to 'power' }\end{array}$ \\
\hline
\end{tabular}

According to oral traditions, the Bunaq of the north-west (as centred on Lamaknen) formed an autonomous region of the Wehali kingdom, a large southern Tetun territory (Therik 2004) and rival to Likosaen, discussed in the previous section. The influence of Wehali on the Bunaq of this region has been thoroughgoing, leaving heavy marks on all aspects of ritual practice. One illustration of this is the widespread adoption of Tetun terms for ritual practice. 
In the examples in Table 8.4, we see that general Tetun terms - typically with some (additional) use in ritual — have been borrowed by the Lamaknen Bunaq with a more restricted and specific ritual meaning. In this, the Bunaq show a historical willingness to accommodate and integrate the ritual concepts of another group into their own customary practice.

\section{The South-West Bunaq Area: From Betun to Suai}

In the south-west, the Bunaq extend in a corridor west from Lolotoen in the north and Suai in the south across western Covalima subdistrict almost reaching into southern Belu, West Timor.

In East Timorese Covalima, the Bunaq occupy the majority of the region that formed the Maukatar enclave (see Fox 2003:15, Map 2). Today, the Maukatar enclave makes up the villages (suco) of Covalima directly north of Suai, such as Holpilat, Taroman, Fatululik, Datotolu and Laktos. From 1860, the Maukatar enclave was recognised as part of the Dutch territory in Timor. The borders of the Maukatar enclave were defined with reference to local, and in particular Bunaq, states. The Dutch claimed Maukatar was theirs on the grounds that it was a part of the Dutch state of Lakmaras, in modern-day Lamaknen, and was joined by that state to other Dutch territories. The Portuguese, however, claimed that since 1859 Lakmaras had been taken over by the Portuguese state of Lamakhitu, another Bunaq kingdom situated in the area of Bobonaro.

Despite Bunaq dominance of the enclave both today and in the recent historical period, the majority of Bunaq villages in the area have placenames with Tetun etymologies - for example: Fatuloro < Tet. fatu 'stone' loro 'sun', Kusilulik $<$ Tet. kusi 'pot' and lulik 'holy', and Lia naPin < Tet. lia 'voice, language' and nain 'lord, father's brother'. This distribution of peoples to placenames suggests that the Bunaq have here too been successful in expanding into new lands and assimilating a previous (probably) Tetun population. In a scenario of displacement of an existing population rather than assimilation of it, we would expect to see significant re-coining of placenames, and thus admixture in the presence of Bunaq and Tetun placenames.

Linguistically, this South-West region of the Bunaq language area is the most phonologically conservative. That is, they have not undergone the sound changes that characterise the North-East dialect, retaining the original sounds of the proto-language instead. This means that the Bunaq must have settled the region before the sound changes began to take effect, thus placing it in the relatively remote past. 
In the western border area of Covalima, the Tetun are in the majority. Bunaq villages are found interwoven amongst Tetun villages stretching south of Fohorem to the coast. The Bunaq in this area were established in the recent historical period in two distinct waves. The newest group is the Bunaq villages in the lower lands along the coast between Suai and the border. These people were resettled by the Indonesian administration from northern Covalima suco such as Fatululik and Taroman as part of a rice-agriculture development program.

The second, older collection of Bunaq villages is situated in the upland parts of the suco of Foholulik and Lalawa, immediately south of Fohorem. These villages have their origins in a massive collective flight out of Bobonaro away from the Japanese Army. Their flight comprises the most significant displacement of Bunaq dating from World War II. The Japanese invaded Timor on 20 February 1942 and within days had overwhelmed the small force of Australian and Dutch troops. Some of these troops managed to evade capture and withdrew into the mountains, from where they waged a guerrilla campaign against the Japanese. The guerrillas spent much of their time in the Bobonaro area and were at different times based in Bobonaro town and Lolotoen. In August 1942, the Japanese carried out a series of reprisals in the area of Bobonaro against the population who had assisted the guerrillas, with, it is believed, tens of thousands killed and many others displaced, as in the case of these Bunaq who settled south of Fohorem.

Across the border, in southern Belu, Bunaq occupy disparate settlements of the Kobalima, Malaka Timur and Raimanuk subdistricts (Map 8.5). Individual Bunaq villages are scattered amongst a majority Tetun population. At the western extreme of the Bunaq area are Haroe and Welaus (noted by Woertelboer 1955:172), a few kilometres east of Betun, while to the north is a handful of isolated villages (I: desa) of Faturika, Renrua and Babulu. Moving east, Bunaq villages are strung out along the road right up to the desa of Alas and Alas Selatan on the border with Timor-Leste.

A single village in this region, Namfalus, originates in the same flight from the Japanese that saw the establishment of Bunaq south of Fohorem. The remainder all trace themselves back to Bunaq villages in the Maukatar enclave. As mentioned above, the enclave was subject to ongoing border disputes between the Portuguese and Dutch colonial administrations, but, in 1904, it was agreed that the lands would be ceded to Portugal in exchange for other areas (Sowash 1948). Following the 1904 agreement, disputes continued over the demarcation of borders, and in 1911 when Portuguese troops moved into Maukatar, they were met by Dutch forces. Clashes continued throughout 1911, before the Dutch agreed to withdraw as per the agreement of 1904. During the fighting of 1911 and following the ceding of the enclave to Portugal, some 5000 of the population 
of Maukatar, mostly Bunaq, decamped to Dutch Timor, in what is now southern Belu. As in Lamaknen, each of these Bunaq settlements has seen new additions from East Timor during the upheavals of 1975 and 1999.

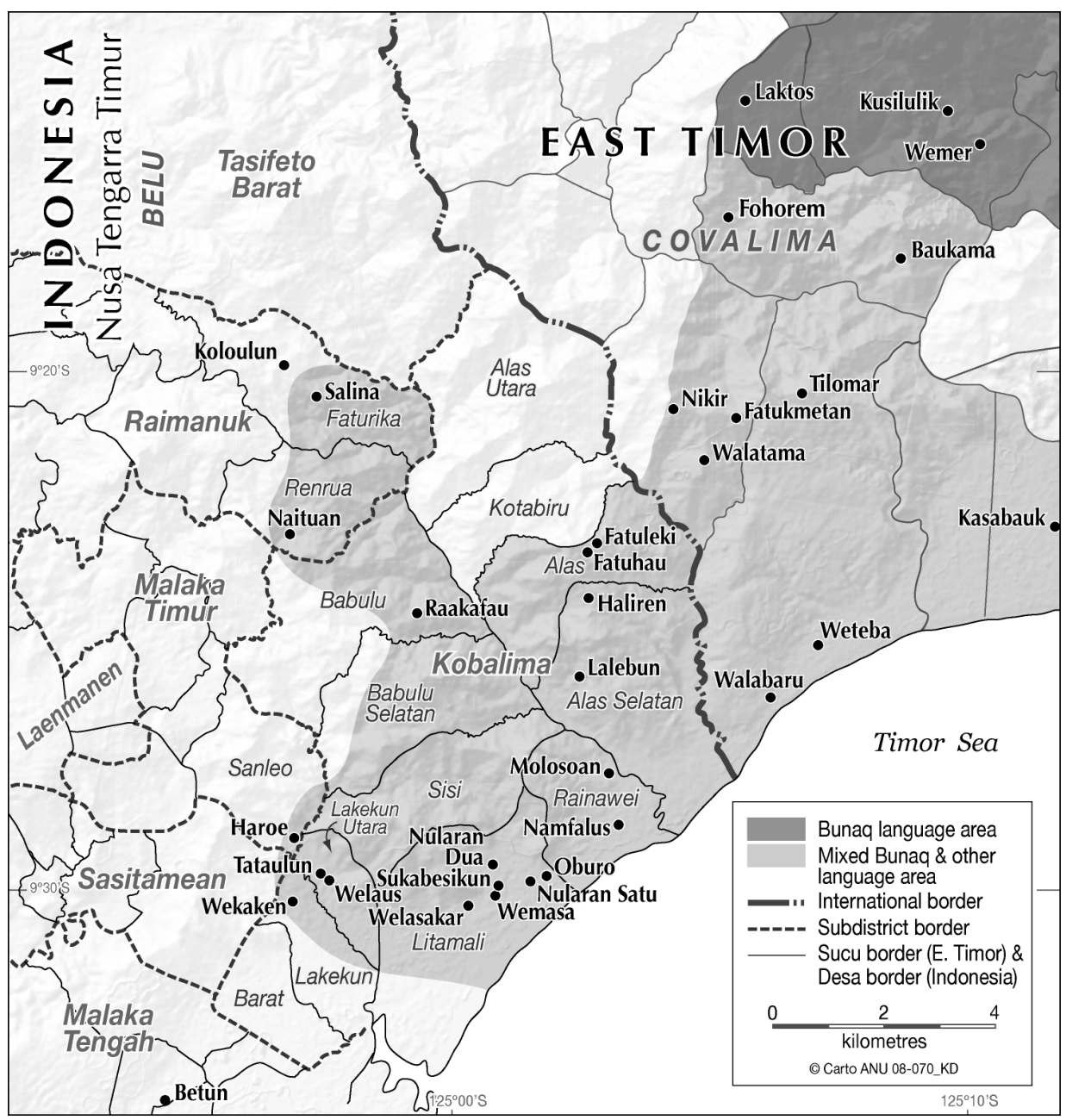

\section{Map 8.5 Bunaq villages in southern Belu and south-western Covalima}

According to local informants, the resettlement of the Maukatar Bunaq was fraught with difficulties due to land disputes with the local Tetun, the refugee Bunaq were forced to move from place to place in Belu until the 1930s when the administration was able to settle them peacefully in their current locations. Nevertheless, Bunaq in southern Belu proudly declare themselves the first refugees from East to West Timor. They trace themselves back to particular villages in Maukatar-for instance, the Bunaq in Raakfao trace their origins to 
Fatuloro in Maukatar and those in Sukabesikun to Belekasak in Maukatar. This regard for their origins persists among this Bunaq diaspora in the face of their ongoing amalgamation into the Tetun majority.

\section{The South-Central Bunaq Area: From Suai to Zumalai}

Much of the southern coast of Timor-Leste was traditionally uninhabited. Bunaq villages in the region between Suai and Zumalai are of recent establishment. Each village traces itself to an older upland origin site. Connections between old and new villages run deep. For instance, inhabitants of Beco, a village situated on the coastal plain east of Suai, identify themselves as coming from Teda, an upland village to the east of Lolotoen. Yet, they had never been to Teda themselves and both they and their parents were born in Beco. This points to the continuing significance of origin place in these villages despite the geographical removal. Indeed, the dialect of Bunaq spoken in these villages also strongly reflects the upland origins in the Lolotoen region with all the typical phonological markers of the North-East dialect. Some dialect mixing with the South-West is apparent in the use of certain lexical items, such as bo?al in place of tina for 'big' and habuhabu in place of taho? for 'cloud'. This reflects the fact that today the most contact these Bunaq have is with speakers of the South-West dialect.

Bunaq villages in the lowland areas of Zumalai district were similarly founded on the basis of upland villages. As in the north-western corner, in lowland areas upland placenames reoccur - for example: Zulotas (literally: 'civet village') has given rise to a twin just north of Zumalai town called Zulokota (literally: 'civet city'). Many of these villages were established during the Indonesian period, with whole villages being brought south to the road on the promise of housing. Linguistically, the villages around Zumalai display a dialect that is entirely consistent with that of the upland settlements - a homogeneity indicative of very recent movement.

\section{The Eastern Bunaq Area: From Zumalai to Betano}

To the east of Zumalai, a corridor of Bunaq villages stretches across southern Ainaro subdistrict into the western-most part of Manufahi (Map 8.6). The peoples of Ainaro and Manufahi both have their origin in the north-eastern Bunaq area. This is shown by the fact that the dialects must have had a glottal stop (?) in 
place of the consonant $\mathrm{r}$ in words such as mar 'farm', as is characteristic of the North-East dialect. The glottal stop has since been lost in the eastern dialects to give forms such as ma 'farm'.

In this area, the Bunaq have intermingled significantly with Mambai, the Austronesian group native to the area. The Bunaq here are typically bilingual in Mambai, and their varieties of Bunaq show the impact of mixing with Mambai neighbours. For instance, the loss of the glottal stop mentioned above and the loss of * $\mathrm{w}$ probably occurred under the influence of Mambai, which lacks both these sounds (Hull 2003). Specific innovations of the Ainaro and Manufahi Bunaq groups are discussed below.

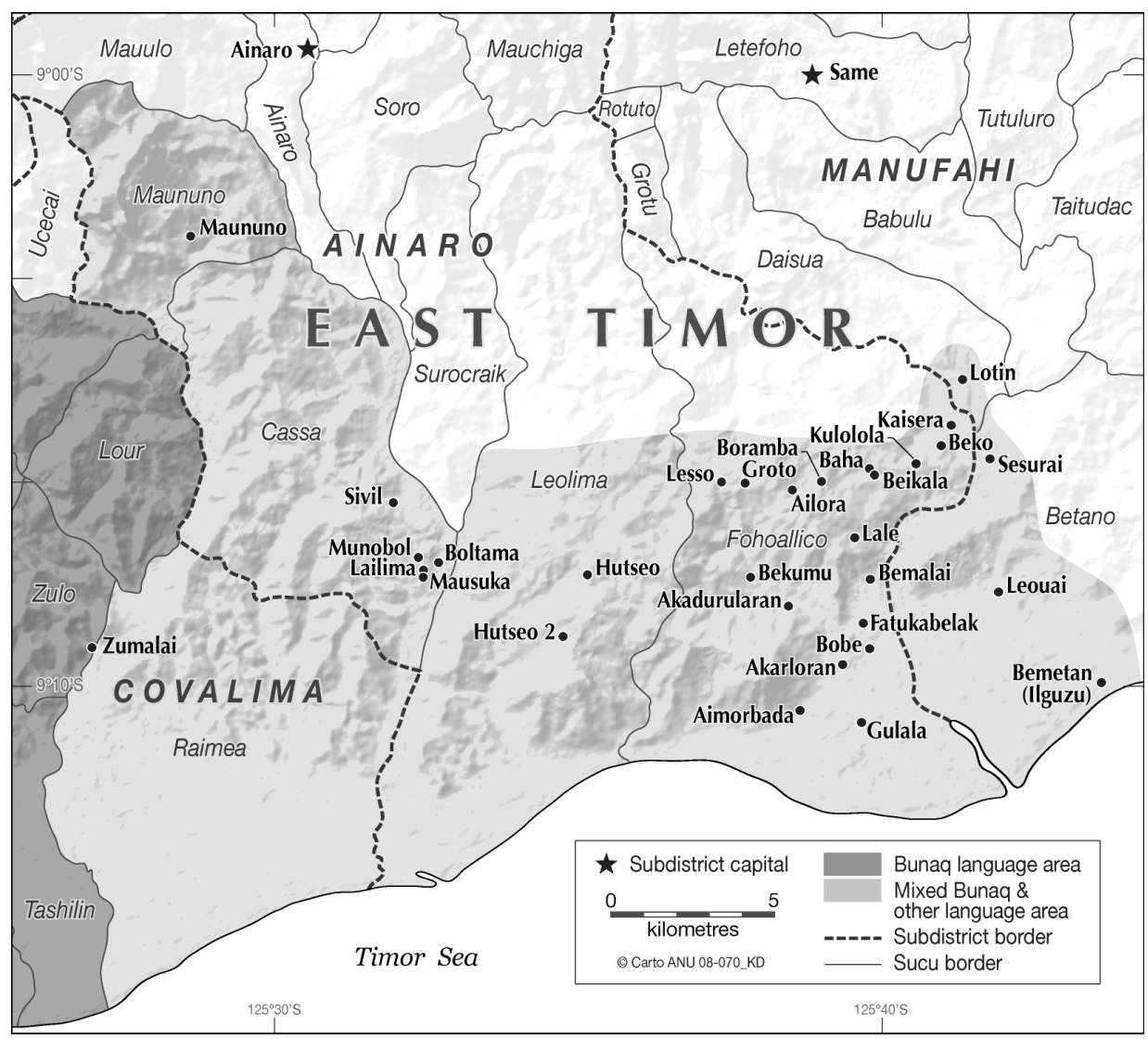

Map 8.6 Bunaq villages in Ainaro and Manufahi

\section{The Bunaq in Ainaro}

In Ainaro the Bunaq occupy the whole of the suco of Maununo. Originally, Maununo contained three discrete villages: Aileu, Mamalau and Mausuka. 
During the Indonesian era, however, the villages were brought together to occupy the single location they do today. To the south of Maununo, Bunaq speakers are spread throughout the suco of Cassa. This group has close ties to the Maununo Bunaq (cf. Rawski 2002 on the bitter enmity between the Maununo and Cassa groups). Further east, the entire suco of Fohoailiku to the south-east of Ainaro is Bunaq. The Fohoailiku Bunaq claim to have moved from western Ainaro due to a dispute between rival Bunaq groups some time in the Portuguese era.

These three groups of Bunaq speakers share particular linguistic features distinct from other groups, which point to their having a single source. In particular, they have the first-person pronoun au ' $\mathrm{I}$ ' from Mambai in place of Bunaq neto ' $I$ '. Pronoun borrowing is cross-linguistically so rare that it is unlikely to have occurred three distinct times amongst the Ainaro Bunaq. More likely, au ' $\mathrm{I}$ ' was borrowed once into an early group of Bunaq speakers in close contact with Mambai and has continued to be used by their descendents as later groups have branched off. Other innovations common to this group include the use of gemel to mean 'big'. This item is used to refer to a 'female animal' in all other Bunaq varieties and derives from eme 'mother'. The semantic innovation of this term in Bunaq Ainaro is again clearly calqued from Mambai inan 'mother', which is also used attributively to mean 'big/large'.

There are conflicting accounts of the origins of these three Bunaq groups, with some traditions claiming the Bunaq to be the original inhabitants and others that they arrived later. Placenames strongly suggest that the Bunaq here moved into an area with a pre-existing Austronesian population. The Bunaq villages in the region all carry Austronesian names. For instance, placenames with the formative mau, as in Mausuka and Maununo, abound; this formative is typical of placenames in the Mambai-Kemak-Tokodede-speaking areas, but is not present in the core Bunaq lands. The other placenames in the Bunaq area are clearly Mambai-for instance: Beikala, a Mambai binominal comprising Mambai bei 'grandparent' and kala 'ancestor', used in ritual speech.

In addition to these three groups with a common source, there are two small Bunaq groups that have different origins and accordingly different linguistic traits. First, the villages of Sivil and Lailima, which are strung along the road south of Ainaro town amongst Mambai settlements, were moved down from the Zumalai area during the Indonesian period. Second, east of Cassa there are two villages of Bunaq speakers amongst the sea of Mambai villages in the suco Leolima, Hutseo and its offspring of the Indonesian period, Hutseo Dua ('Hutseo $\left.\mathrm{II}^{\prime}\right)$. The Bunaq dialect spoken in these villages is still strongly north-eastern in flavour, consistent with a recent move from the region of Zumalai.

Bunaq in these areas show significant cultural entwinement with their Mambai neighbours. First, unlike the matrilineal western Bunaq, the Bunaq here have 
a patrilineal system of marriage and descent, following the pattern of the Mambai. Second, there is an inventory of shared myth between the two groups in the area. For instance, the Maununo Bunaq and Mambai both claim to be descended from the same pair of ancestors, and the mountain onto which the apical ancestors descended has both a Bunaq name (lolo guzu muk po) and a Mambai one (manu aman parasa) (see also Corte-Real 1998 for discussion of these terms). Such socio-cultural features set the eastern Bunaq off from the western Bunaq and point to not only a long span of linguistic contact with the Mambai, but also the Bunaq's acculturation to Mambai cultural norms and their view of the landscape and its ritual significance.

\section{The Bunaq in Manufahi}

In Manufahi, there are four Bunaq villages scattered along the road south of the main town, Same. The first Bunaq village established in this area is Lotin (also known as Loti). This group moved from Aiasa, near modern-day Bobonaro town, about 1891. According to oral histories, the move was prompted by a dispute with the ruler (régulo) of Bobonaro after the villagers of Aiasa killed his wife. The régulo called in Portuguese forces in August 1891, whereupon a series of bloody clashes took place (Pélissier 1996:119-20) and resulted in the flight of some of Aiasa village to Manufahi.

The original Lotin village was located to the north of the suco of Daisua - that is, isolated from other Bunaq-speaking communities to the west and in contact with speakers of the Mambai and Lakalei languages. The linguistic outcome of this isolation is that the descendents of the settlers from Aiasa speak a radically different dialect from that found in other parts of the Bunaq-speaking area. Lexically, the dialect is characterised by a range of semantic innovations whereby certain words have undergone significant shifts in meaning. What is more, in addition to borrowings from the local contacts' languages, entirely new words have been innovated in Lotin. Examples are given in Table 8.5.

\section{Table 8.5 Some Lexical Innovations in Lotin Bunaq}

\begin{tabular}{llll}
\hline Bunaq Lotin & & Other Bunaq & \\
\hline esu & 'tree' & esu & 'spine of palm leaf' \\
moel & 'absent, not exist' & muel & 'be thin' \\
hono & 'present, exist' & hono & 'be (ritual only)' \\
neun & 'play' & -- & -- \\
ikir & 'cassava' & -- & -- \\
be & 'search' & -- & -- \\
kaman & 'big' & -- & -- \\
\hline
\end{tabular}


Following the Boaventura rebellion, the Portuguese resettled some of the Lotin Bunaq in lower lands. The modern village of Lotin is some kilometres south of the original village, and two further villages, Il Guzu (literally 'black water' in Bunaq, also known in Mambai as Bemetan) and Leoai, were established for the Lotin Bunaq close to the coast. The three villages share a dialect distinct from all other Bunaq groups. Later, the remaining villagers of the original Lotin were resettled from the mountainous interior during the Indonesian period to the current site, marked on Map 8.7.

The fourth Bunaq village in Manufahi is Sesurai, located on the road between Lotin and Leoai. According to tradition, the Sesurai Bunaq fled from the Zumalai area to Manufahi some time in the Portuguese era. The dialect of Bunaq spoken in Sesurai has some characteristics consistent with the North-East dialect spoken in Zumalai, but has taken on some lexical traits of Lotin Bunaq, such as esu for 'tree' in place of hotel.

\section{The Bunaq Expansions in Comparative Perspective}

In the preceding sections I have sought to document the process of Bunaq expansion. Closely tracking placename dispersal, I show that the Bunaq have expanded from a core area in the mountains of central-eastern Bobonaro and north-eastern Covalima subdistricts. Corroborating evidence for seeing this area as the Bunaq homeland was presented in the form of Kemak/Mambai vocabulary across all Bunaq dialects. This suggests a mountainous homeland close to speakers of the precursors of modern-day Kemak/Mambai.

Using placenames, dialectal data and oral histories, three major types of Bunaq movement from the homeland can be discerned. They are: a) upland expansions; b) lowland expansions; and c) flights. How these different movements have shaped the Bunaq area is summarised in Map 8.7. Upland expansions appear to have come about as Bunaq have moved into an adjacent upland area, gradually overwhelming an incumbent Austronesian population. Placenames in these areas are of mixed origin, having both Bunaq and Austronesian etymologies. These expansions represent the oldest layer of retrievable movements for which only vague oral histories exist. Dialectally, such areas of old expansion are characterised by having a distinct dialect, such as that of Lamaknen, Maukatar (the centre of the South-West dialect expansion) and Maununo (the centre of the Ainaro dialect expansion). In lowland expansions, Bunaq have gradually moved into an adjacent lowland area that was previously or largely uninhabited. Placenames in these areas are Bunaq, either reflecting upland village names or 
being coined anew. ${ }^{2}$ Oral histories for these expansions identify specific upland origins for a new village, and point to settlement having occurred within the past several generations. Due to the usual maintenance of ritual ties between the two areas, the dialects of new lowland villages remain consistent with those of the older source villages.

Flights are long-distance displacements of Bunaq, triggered by conflict in their area of origin. Placenames in regions settled by fleeing Bunaq typically reflect the language of the incumbent group. These movements characteristically represent recent historical events for which relatively precise historical records and/or oral histories exist. The dialects spoken by Bunaq villages established after a flight typically reflect the region of origin, but may be mixed with the speech of the incumbent people, speaking either another Bunaq dialect or a neighbouring Austronesian language group.

\section{Towards An Understanding of Papuan- Austronesian Interaction in Timor}

The conventional understanding of Austronesian history involves their expansion across the Philippine and Indonesian archipelagos, overwhelming pre-existing populations and transforming them into speakers of Austronesian languages (Bellwood 1998). McWilliam (2007) argues for the opposite scenario in far eastern Timor, suggesting that the Austronesian cultural features of the Fataluku point to their having taken over a prior Austronesian-speaking people. Following proposals in Wurm et al. (1975) and Hull (2004), McWilliam puts forward the argument that the Fataluku people may have arrived in Timor after the Austronesians, colonising them and taking on many of their cultural practices. A similar expansion of Makasai people is suggested to have occurred.

In this chapter, however, I have outlined a different manner of expansion for the Bunaq, one that has consequences for our broader understanding of the history of the Papuan groups in Timor. I have shown that detailed examination of placenames firmly locates the Bunaq in central Timor before the Austronesian arrival. This is significant since, if the Bunaq precede the Austronesians, the other Papuan languages must also be seen to have been prior. If not, we are unable to explain the cognate non-Austronesian vocabulary shared by the Papuans of eastern Timor and Bunaq in central Timor, examples of which are given in Table 8.6. The presence of such lexemes cannot be dismissed as having arisen through later diffusion by contact as the Austronesian languages

2 The exception to this is that new lowland villages created by administrators do not typically have Bunaq names. 
intervene between Bunaq and the others. Instead, we must reconstruct the items to a 'proto-Timor' Papuan language from which the modern languages Bunaq, Makasai and Fataluku are all descended.

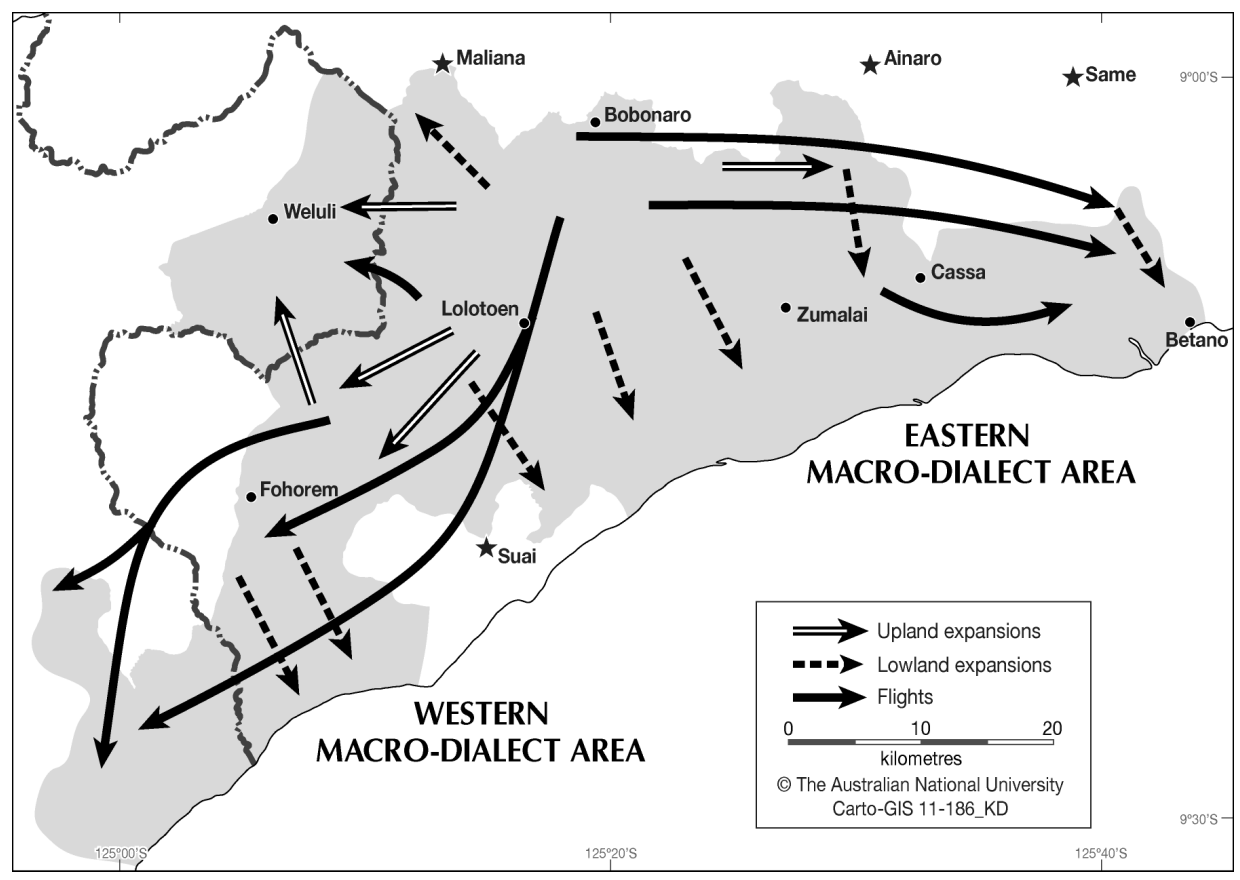

\section{Map 8.7 Major patterns of the Bunaq expansion}

This historical circumstance leaves us with the need to explain the presence of so many Austronesian cultural features amongst Papuan language-speaking groups in Timor. I pointed out in this chapter that Austronesian cultural influence on Bunaq in the form of Kemak/Mambai vocabulary can already be discerned even in the earliest times before the beginning of the Bunaq expansion. The Austronesian cultural stamp on the Papuan languages could then be understandable simply as the normal outcome of significant and prolonged contact with a more prestigious neighbouring cultural group. The greater question remaining for future comparative Timorese studies is by what mechanisms have the Papuan groups in Timor been subsequently able to turn the tables and successfully expand and assimilate established Austronesian peoples. 
Land and Life in Timor-Leste: Ethnographic essays

Table 8.6 Some Cognate Sets in Non-Austronesian Languages of Timor

\begin{tabular}{lllll}
\hline Item & Bunaq & Makasai & Fataluku & Proto-Timor \\
\hline 'stand' & net & etenaa & inate & ${ }^{*}$ (e)nate \\
'woman' & pana & pana & fana & ${ }^{*}$ pana \\
'one' & uen & $u$ & ukan & ${ }^{*}$ kuna \\
'earth' & muk & mu?a & mu?a & ${ }^{*}$ muga \\
'sit' & mit & mi?i & mire & ${ }^{*}$ midge \\
'sleep' & tier & ta'e & taja & ${ }^{*}$ tade \\
'give' & -ini & gini & ina & ${ }^{*}$ (g)-ina \\
'tree, wood' & hotel & ete & ate & ${ }^{*}$ wate \\
'fire' & hoto & ada & aca & ${ }^{*}$ wata \\
'mouse, rat' & zul & cura & dura & ${ }^{*}$ dzila \\
'water' & il & ira & ira & ${ }^{*}$ ila \\
\hline
\end{tabular}

A full investigation of the various mechanisms that could have played a role in each of the Bunaq is beyond the scope of this chapter. I will, however, briefly discuss a general characteristic of the Bunaq that I propose has aided their expansion-namely, their readiness to incorporate aspects of Austronesian language and society. Throughout this chapter, I have outlined cases - primarily on the basis of different linguistic data - of Bunaq accommodation and adaptation of the cultural categories of their Austronesian neighbours. I tentatively suggest here that it is this inclusive cultural attitude that has enabled the Bunaq to successfully expand into new lands, whilst still maintaining a linguistic identity distinct from the incumbent Austronesian populations.

This pattern is particularly notable for the fact that it bucks the trend observed elsewhere in Melanesia, where differentiation is typically socially encouraged (Ross 1997; Thurston 1989). Numerous studies have shown that in Melanesia widespread bilingualism between neighbouring groups in contact is coupled with pressure within individual groups to differentiate from their neighbours. The result of these counter-forces is to promote on the one hand broad cultural and lexical isomorphism, but on the other hand heterogeneity. The structural parallelism results from bilingualism and the accompanying pressure towards the full translatability of concepts (Gumperz 1971), while the emblematic function of the lexicon drives formal differentiation of the words themselves.

That this kind of divergence drive has not occurred with the Bunaq in central Timor might be best explained by the fact that the Bunaq would have already been differentiated from the very start of their engagement with Austronesians. As mentioned at the beginning of this chapter, even today, after more than a millennium of contact, the Bunaq and their language are regarded as 'other' by their Austronesian neighbours. Thus, in restructuring their own cultural inventory and accommodating aspects of Austronesian language and society, 
Bunaq groups must not have seen a threat to their own identity, but rather perhaps an opportunity to establish themselves and develop relationships with contact groups in new lands.

\section{References}

Australian War Memorial n.a., Independent Company war diary, AWM52/25/3/2: 2/2, Australian War Memorial, Canberra.

Bellwood, P. 1998, 'The archaeology of Papuan and Austronesian prehistory in the northern Moluccas, eastern Indonesia', in R. Blench and M. Spriggs (eds), Archaeology and Language II: Correlating archaeological and linguistic hypotheses, Routledge, London and New York, pp. 128-40.

Berthe, L. 1963, 'Morpho-syntaxe du Bunaq (Timor central)', L'Homme, (January-April), pp. 106-16.

Corte-Real, B. de 1998, Mambae and its verbal art genres: a cultural reflection of Suru-Ainaro, East Timor, PhD thesis, Macquarie University, Sydney.

Fox, James J. 2003, 'Tracing the path, recounting the past: historical perspectives on Timor', in James J. Fox and Dionisio Babo Soares (eds), Out of the Ashes, ANU E Press, Canberra.

Gumperz, J. J. 1971, 'Convergence and pidginization', in D. Hymes (ed.), Pidginization and Creolization of Languages, Cambridge University Press, Cambridge.

Hull, G. 2003, Southern Mambai, East Timor Language Profiles No. 5, Instituto Nacional de Linguística, Universidade Nacional Timor Lorosa'e, Dili.

Hull G. 2004, 'The Papuan languages of Timor', Studies in Languages and Cultures of East Timor, vol. 6, pp. 23-99.

McWilliam, A. R. 2007, 'Austronesians in linguistic disguise: Fataluku cultural fusion in East Timor', Journal of Southeast Asian Studies, vol. 38, pp. 355-75.

Pélissier, R. 1996, Timor en guerre: le crocodile et les portugais, Pélissier, Orgeval, France.

Rawski, F. 2002, 'Truth-seeking and local histories in East Timor', Asia-Pacific Journal on Human Rights and the Law, vol. 1, pp. 77-96. 
Ross, M. 1997, 'Social networks and kinds of speech-community event', in R. Blench and M. Spriggs (eds), Archaeology and Language 1: Theoretical and methodological orientations, Routledge, London, pp. 209-61.

Ross, M. D. 2006, 'Metatypy', in K. Brown (ed.), Encyclopedia of Language and Linguistics, Elsevier, Oxford.

Sowash, W. B. 1948, 'Colonial rivalries in Timor', Far Eastern Quarterly, vol. 7, no. 3, pp. 227-35.

Spillet, P. G. 1999, The pre-colonial history of the island of Timor together with some notes on the Makassan influence on the island, Unpublished manuscript, Museum and Art Gallery of the Northern Territory, Darwin.

Therik, T. 2004, Wehali. The Female Land: Traditions of a Timorese ritual centre, Pandanus Books, Canberra.

Thurston, William 1989, 'How exoteric languages build a lexicon: esoterogeny in Western New Britain', in Ray Harlow and Robin Hooper (eds), VICAL 1: Oceanic languages, Papers from the Fifth International Conference on Austronesian Linguistics. Part 2, Linguistic Society of New Zealand, Auckland, pp. 555-79.

Woertelboer, W. 1955, 'Zur Sprache und Kultur der Belu (Timor)', Anthropos, vol. 50, no. 1, pp. 155-200.

Wurm, Stephen, Laycock, D. C., Voorhoeve, C. L. and Dutton, T. E. 1975, 'Papuan linguistic prehistory, and past language migrations in the New Guinea area', in Stephen Wurm (ed.), New Guinea Area Languages and Language Study. Volume 1: Papuan languages and the New Guinea linguistic scene, Pacific Linguistics, Canberra. 